УДК 614.351.77

В. Г. Гінзбург, Т. М. Полішко, П. М. Полушкін, Д. В. Гальченко

Дніпропетровський національний університет ім. Олеся Гончара

\title{
МОЖЛИВІ СХИЛЬНОСТІ ДО ВЖИВАННЯ ПСИХОСТИМУЛЯТОРІВ, ТОКСИЧНИХ, НАРКОТИЧНИХ РЕЧОВИН СЕРЕД МОЛОДІ ТА СТУДЕНТІВ
}

3 урахуванням сучасних досягнень медицини, психології, соціології здійснено комплексне дослідження можливих схильностей до вживання психостимуляторів, токсичних, наркотичних речовин серед учнів, студентів, молоді 3 подальшим визначенням варіантів первинної профілактики цих схильностей. Проаналізовано основні та додаткові чинники ризику, що сприяють реалізації паління, зловживання алкогольумісними продуктами, психостимуляторами, наркоманії, токсикоманії в молодіжному середовищі. Досліджено динаміку можливих впливів медичних, психологічних, соціальних чинників зі спробою короткочасного прогнозування та визначеня рангових місць.

В. Г. Гинзбург, Т. Н. Полишко, П. Н. Полушкин, Д. В. Гальченко

Днепропетровский наџиональный университет им. Олеся Гончара

\section{ВОЗМОЖНЫЕ НАКЛОННОСТИ К УПОТРЕБЛЕНИЮ ПСИХОСТИМУЛЯТОРОВ, ТОКСИЧЕСКИХ, НАРКОТИЧЕСКИХ ВЕЩЕСТВ СРЕДИ МОЛОДЕЖИ И СТУДЕНТОВ}

С учетом современных достижений медицины, психологии, социологии предпринята попытка комплексного исследования возможных наклонностей к употреблению психостимуляторов, токсических, наркотических веществ среди учащихся, студентов, молодежи с последующим определением вариантов первичной профилактики этих наклонностей. Проанализированы основные и дополнительные факторы риска, способствующие реализации курения, злоупотребления алкогольсодержащими продуктами, психостимуляторами, токсикомании, наркомании в молодежной среде. Исследована динамика возможных влияний медицинских, психологических, социальных факторов с попыткой кратковременного прогнозирования и определения рангових мест.

\section{G. Ginzburg, T. N. Polichko, P. M. Polushkin, D. V. Galchenko}

Oles' Honchar Dnipropetrovsk National University

\section{POSSIBLE INCLINATIONS \\ FOR PSYCHOSTIMULANT, TOXIC AGENT AND DRUG ABUSE AMONG YOUTHS AND STUDENTS}

Taking into account modern achievements in medicine, psychology and sociology, the attempt at complex research of possible inclinations for psychostimulant, toxic agent and drug abuse among youths and students was made with the subsequent determination of the possible alternates of primary prevention. It is analysed the basic and additional risk factors promoting smoking, drinking, psychostimulant abuse, toxicomania and narcomania among young people. The dynamics of possible influences of medical, psychological and social factors is studied. The attempt of short-term prognostication and ranking was made. 


\section{Вступ}

Формування здоров'я визначається способом життя людини, станом навколишнього середовища [1-3]. Основним фактором ризику виникнення смертельного захворювання раку легень $\epsilon$ паління. Однак виробництво та реалізація тютюнових виробів, незважаючи на оголошену боротьбу з палінням, з року в рік не зменшується, а тільки збільшується. Серйозне занепокоєння викликає те, що до паління широко залучаються діти, підлітки та молодь. У віці 12-13 років палять 4-5 \% хлопців і 2-3 \% дівчат, у 17 років - 34 і 7 \%, відповідно. Білышість юнаків починає палити до 18-річного віку (84,2 \% усіх опитаних курців), а дівчата - після 17 років. Виникненню та закріпленню звички палити сприяє «паливна» поведінка та позитивне ставлення до паління оточующих, насамперед друзів, батьків, викладачів, улюблених акторів, співаків [4; 5].

Серед чоловіків старше 18 років палять $67 \%$ міських жителів і $69 \%$ сільських. Серед жінок ці показники становлять відповідно 35 і 32 \%. Паління багатьма розглядається як один із шляхів задоволення потреби у неформальному спілкуванні. Починаючи палити, ніхто не замислюється про згубні наслідки для здоров'я. У той же час інфаркт міокарда серед курців спостерігається у 20 разів частіше, ніж серед тих, хто не палить, і в 6 разів частіше серед осіб у віці 25-35 років. Облітеруючий ендартериїт вважається хворобою курців: 98 \% хворих на нього - завзяті курці, причому недуга спостерігається головним чином у чоловіків 20-40 років. У курців-чоловіків у віці 40-55 років ризик виникнення раку горла підвищується шестиразово, раку органів ротової порожнини - десятиразово. 50 \% нікотину йде у повітря приміщень і вдихається тими, хто не палить. Таке «пасивне паління» протягом години рівносильне 4 випаленим цигаркам. Про це повинен замислюватися кожен курець і намагатися кинути палити [6; 7].

Алкоголь також нищить здоров'я. У результаті вживання спиртних напоїв ушкоджуються всі органи людини: серце, легені, печінка, шлунок тощо. Але найтяжче страждає мозок. При вживанні алкоголю найбільша його концентрація спостерігається саме в мозку. Особливо страждає від нього кора головного мозку, а вона складає лише $2 \%$ ваги тіла. Алкоголь руйнує кору головного мозку, де закладено всю розумову діяльність, пам'ять, творчість і моральність. Алкоголізм ускладнює, уповільнює розумову діяльність, шкодить нервовій системі, ослаблює силу волі, самоконтроль над вчинками, спричинює розвиток таких рис як грубість, самовпевненість, безвідповідальне ставлення до своїх обов'язків у сім'ї, трудовому колективі, суспільстві. Завдання викорінення пияцтва полягає, по суті, у тому, щоб навчити людину ясно усвідомлювати шкідливість вживання спиртних напоїв і вести тверезий спосіб життя. Багато хто помилково вважає, ніби загрозу їм самим і суспільству становить лише крайність, тобто пиття регулярне й у великій кількості, а от у «культурному» вживанні спиртного нічого поганого немає. Дарма хтось думає, що спиртне, вжите «в міру», знижує втому, підвищує тонус. На всіх людей (і на тих, про кого говорять, що вони «вміють пити») алкоголь діє однаково негативно. Тi, хто зловживає алкоголем, хворіють у середньому удвічі частіше, учетверо довше, а живуть на $15-20$ років менше, ніж решта [8; 10]. За даними ВООЗ, 40 \% медичних видатків йдуть на лікування алкоголізму та хвороб, викликаних алкоголем. Зловживання алкоголем для звичайної сім'ї спричинює збільшення кількості дітей із вадами розвитку.

Токсикоманія - один із найзлоякісніших видів наркоманії. Викликаючи серйозне порушення роботи організму та сильну залежність, токсикоманія відрізняється від наркоманії лише в юридичному аспекті: вона викликається вживанням речовин, 
офіційно не віднесених до групи наркотиків, і на неї не поширюються правові та кримінальні акти, що діють відносно наркоманів. За останні 20 років токсикоманія вдихання «летких речовин», що наркотично діють, - набула характеру епідемії. Щороку із пакетами на голові гинуть сотні дітей і підлітків. Середній вік таких «споживачів» продукції хімічної промисловості - 8-15 років. Ураховуючи масштаби поширення токсикоманії, те необоротне руйнування, яке вона проводить у дитячому організмі та психіці, можна серйозно говорити про загрозу майбутньому нації. У нашій країні зловживання інгалянтами почалося наприкінці 1960-х років. На сьогодні токсикоманію можна вважати національним лихом [6].

Залучення до наркотиків частіше за все відбувається через цікавість. Цим захоплюються ті, хто не дбає про себе, веде безробітне життя. Вони, як правило, позбавлені серйозних ідейних і моральних переконань. Окремі молоді люди вживають наркотики, не знаючи про страшні наслідки їх нищівної дії на здоров'я. До вживання наркотиків чи токсичних речовин залучаються підлітки з дефектами виховання, несформованою незрілою особистістю за відсутності контролю за їх поведінкою з боку батьків, вихователів, педагогів.

Наркоман (токсикоман) - тяжко хвора людина, хвороба якої виникла винятково 3 iï власної вини. Страждає не лише психіка, а і серцево-судинна, нервова системи, нирки, печінка та інші життєво важливі органи. Хронічні отруєння наркотиками швидко призводять до інвалідності та смерті у молодому віці. Безвинно покараними стають діти наркоманів: нерідко вони народжуються 3 фізичними та психічними вадами, деякі - 3 уродженою пристрастю до наркотиків $[9 ; 10]$. Наркомани (токсикомани) постійно втягують у свої лави нестійких підлітків, залучають їх до вживання наркотиків. Кожний наркоман - потенційний розповсюджувач «інфекції», що робить його соціально небезпечним.

Україна не могла довго перебувати поза глобальною «епідемією» зловживання алкогольумісними продуктами, палінням, різними стимуляторами; токсикоманії, наркоманії. Значущість цієї проблеми у країні наростає з кожним роком. Тому мета нашої роботи - оцінка можливих схильностей до вживання алкогольумісних продуктів, паління, психостимуляторів, токсичних, наркотичних речовин серед учнів і студентів із подальшим визначенням можливих варіантів первинної профілактики цих схильностей.

\section{Матеріал і методи досліджень}

Розроблено та випробувано спеціальні анкети. Передбачено анонімне анкетування за спеціально розробленими 16 тестами-питаннями 100 учнів 9, 10, 11-го класів і 100 студентів 1-4-го курсів гуманітарного фаху ДНУ ім Олеся Гончара. Отримані результати груповано та оброблено за допомогою факторного аналізу з метою визначення імовірністі впливу на людину медико-біологічних, психологічних, соціальнопобутових факторів. За допомогою використання критерію відповідності $\chi^{2}$ визначено короткочасне прогнозування можливої схильності людини до вживання алкогольумісних продуктів, паління, психостимуляторів, токсичних, наркотичних речовин.

Відповідно до літературних даних [2] до психологічного розділу анкети включено питання, пов'язані з деякими особливостями сучасної психіки людини:

- реакції протесту з комплексом переживань у вигляді активного (помста) або пасивного (синдрому депресіі) чи інших варіантів;

- реакції наслідування (імітації) асоціальним елементам поведінки (паління, вживання алкоголю, наркотиків тощо); 
- акцентуація характеру у вигляді посилення окремих рис вдачі, вибірковості реакцій на психічну дію (явна та прихована агресії):

1) астено-невротичний тип, що виникає на фоні природженої невропатії (природжена нервовість) у вигляді порушень сну, апетиту, сомнамбулізму, сноговоріння, нічних страхів, вибірковості до їжі, відрижки, диспепсії, схильності до психопатії та інших відхилень;

2) істероїдний тип у вигляді брехливості, бажання себе прикрасити, привернути до себе увагу, егоцентризму, претензії на універсальне лідерство в усіх сферах;

3) нестійкий тип із неслухняністю, непосидючістю, навіюваністю, підвищеною тягою до задоволень, розваг, компаній із делінквентною поведінкою.

\section{Результати та їх обговорення}

Аналізуючи відповіді на питання психологічної частини анкети, слід визначити, що комплекс психологічних факторів впливає на схильності молодої людини. У 44,5 \% респондентів визначається реакція імітації, у 36,0 \% - спостерігається акцентуація характеру. На третьому місці - різні варіанти реакції активного чи пасивного протесту людини - до 29,0 \%. За віковими групами та статтю з боку психологічних факторів визначається найвиразніший вплив на схильності людини до 31,0 \% у вікових групах чоловіків 16-17 і 20-21 років. У жінок деякий вплив психологічних факторів у межах 28-29\% визначається у вікових групах 314 до 23 років із відносним приростом до 8$9 \%$ у групах $16-17$ і $20-21$ років.

Найвпливовішою з окремих психологічних факторів у групі учнів чоловічої статі $\epsilon$ реакція імітації - 9,5 \%, жінок - 8,5 \% (табл. 1). У групі студентів також у чоловіків вплив психологічного фактора «реакція імітації» складає - 9,5 \% у жінок - до 7,5 \%. З усіх психологічних факторів ознаки значного впливу на схильності жінок мають фактори нестійкої акцентуації характеру (до 36,0 \%) та реакції пасивного протесту $(16,0$ \%).

До групи соціально-побутових факторів включені питання, що характеризують соціальні умови, в яких живе людина. Тому пункт поділено на підпункти, що стосуються сім'ї. Наприклад, у шлюбі народився чи не в шлюбі, у повній чи неповній сім'ї жила дитина, вік батьків, заможність чи незаможність батьків, а також наявність друзів. Для дослідження сприятливісті побутових умов - це відсутність витяжки газових плит, водоочисників, розташування вікон на затіненому боці та інші [3].

Можливий вплив соціально-побутових факторів на схильності людини (табл. 2) найбільший серед студентів $(26,5 \%)$ та учнів $(18,5 \%)$ чоловічої статі. Серед студенток $(21,5 \%)$ та учениць $(18,0 \%)$ він дещо менший. Інші соціально-побутові фактори, згідно з сучасними літературними даними, також впливають на формування схильностей людини, однак обмежність кількості об'єктів дослідження не дозволяє нам визначитися щодо цих соціально-побутових факторів.

До групи медико-біологічних факторів (табл. 3) віднесені питання щодо народження (доношені чи недоношені), харчування, самооцінювання отруєнь в анамнезі людини, а також спадкова схильність до можливих проявів алкоголізму, токсикоманії, наркоманії [4]. Відповідно до загальноприйнятих уявлень серед групи медикобіологічних факторів та їх впливу на схильності людини визначено спадковість до шкідливих звичок, наркоманії. У нашому дослідженні визначено спадкову схильність до різних психостимуляторів, алкогольумісних продуктів. Визначено перше рангове місце у чоловіків за вживанням психостимуляторів $(28,0 \%)$, схильністю до алкогольумісних продуктів (14,5\%), у тієї ж кількості студентів - відповідно 6,0 і $9,0 \%$, в учнів - 12,0 і 5,5\%. Серед студенток спадкова схильність до стимуляторів 
реєструється у $17,5 \%$, в учениць - у $12,5 \%$, до вживання алкогольумісних продуктів 4,0 і 5,5 \%, відповідно. Спадкова схильність до наркотиків визначена в опитаних чоловіків (1,5\%).

Таблиия 1

Вплив психологічних факторів (\%) на схильність людини до вживання

психостимуляторів, токсичних, наркотичних речовин і алкоголю

\begin{tabular}{|c|c|c|c|c|c|c|c|c|c|c|c|}
\hline \multirow{2}{*}{$\begin{array}{l}\text { Вік, } \\
\text { років }\end{array}$} & \multirow[b]{2}{*}{ Стать } & \multicolumn{3}{|c|}{ Реакції протесту } & \multicolumn{3}{|c|}{ Реакції імітації, вживання } & \multicolumn{3}{|c|}{ Акцентуація характеру } & \multirow[b]{2}{*}{ Разом } \\
\hline & & активна & пасивна & паління & $\begin{array}{c}\text { алколь- } \\
\text { на }\end{array}$ & $\begin{array}{c}\text { токси- } \\
\text { чна }\end{array}$ & $\begin{array}{c}\text { нарко- } \\
\text { манічна }\end{array}$ & $\begin{array}{c}\text { астено- } \\
\text { невротична }\end{array}$ & $\begin{array}{c}\text { істе- } \\
\text { рична }\end{array}$ & нестійка & \\
\hline \multirow{2}{*}{$14-15$} & чоловіча & 0,5 & 2,0 & 10,0 & 6,5 & 0,5 & 0,5 & 3,0 & 0,5 & 3,5 & 27,0 \\
\hline & жіноча & 1,0 & 3,5 & 3,0 & 3,5 & 0,0 & 0,0 & 4,0 & 0,5 & 3,5 & 19,0 \\
\hline \multirow{2}{*}{$16-17$} & чоловіча & 1,0 & 4,0 & 7,5 & 9,5 & 0,5 & 0,5 & 4,5 & 0,0 & 5,5 & 33,0 \\
\hline & жіноча & 1,5 & 4,5 & 5,0 & 8,5 & 0,0 & 0,0 & 3,5 & 0,5 & 6,0 & 29,5 \\
\hline \multirow{2}{*}{$18-19$} & чоловіча & 0,5 & 4,0 & 6,0 & 6,0 & 0,0 & 1,0 & 2,5 & 0,0 & 3,5 & 23,5 \\
\hline & жіноча & 0,5 & 4,5 & 4,0 & 7,5 & 0,0 & 0,0 & 3,0 & 0,0 & 6,0 & 25,5 \\
\hline \multirow{2}{*}{$20-21$} & чоловіча & 0,0 & 2,0 & 8,5 & 9,5 & 0,0 & 2,5 & 1,0 & 0,0 & 6,5 & 30,0 \\
\hline & жіноча & 0,0 & 2,5 & 6,5 & 7,5 & 0,0 & 2,0 & 1,0 & 0,0 & 7,0 & 26,5 \\
\hline \multirow{2}{*}{$22-23$} & чоловіча & 0,0 & 0,5 & 7,0 & 7,5 & 0,0 & 1,0 & 1,0 & 0,0 & 6,0 & 23,0 \\
\hline & жіноча & 0,0 & 1,0 & 6,0 & 6,5 & 0,0 & 1,0 & 1,0 & 0,0 & 7,0 & 22,5 \\
\hline \multirow{2}{*}{$24-25$} & чоловіча & 0,0 & 0,0 & 4,0 & 3,5 & 0,0 & 0,5 & 0,5 & 0,0 & 3,5 & 12,0 \\
\hline & жіноча & 0,0 & 0,5 & 3,5 & 4,0 & 0,0 & 0,5 & 0,5 & 0,0 & 5,0 & 14,0 \\
\hline \multirow{2}{*}{$>26$} & чоловіча & 0,0 & 0,0 & 2,0 & 2,0 & 0,0 & 0,0 & 0,0 & 0,0 & 1,5 & 5,5 \\
\hline & жіноча & 0,0 & 0,0 & 2,0 & 2,5 & 0,0 & 0,0 & 0,0 & 0,0 & 1,5 & 6,0 \\
\hline \multirow{2}{*}{ Разом } & чоловіча & 2,0 & 12,5 & 40,0 & 44,5 & 1,0 & 6,0 & 12,5 & 0,5 & 30,0 & 149,0 \\
\hline & жіноча & 3,0 & 16,5 & 30,0 & 40,0 & 0,0 & 3,5 & 13,0 & 1,0 & 36,0 & 143,0 \\
\hline
\end{tabular}

Вплив соціально-побутових факторів (\%) на схильності людини

Таблиия 2

\begin{tabular}{|c|c|c|c|c|c|c|c|c|c|c|c|}
\hline \multirow{2}{*}{$\begin{array}{l}\text { Вік, } \\
\text { років }\end{array}$} & \multirow[t]{2}{*}{ Стать } & \multicolumn{2}{|c|}{$\begin{array}{c}\text { Заможність } \\
\text { сім’ї }\end{array}$} & \multicolumn{2}{|c|}{$\begin{array}{c}\text { Народився } \\
\text { у шлюбі }\end{array}$} & \multicolumn{2}{|c|}{$\begin{array}{c}\text { У повних } \\
\text { сім'ях }\end{array}$} & \multicolumn{2}{|c|}{$\begin{array}{c}\text { Сприятливі } \\
\text { умови життя }\end{array}$} & \multicolumn{2}{|c|}{$\begin{array}{c}\text { Наявність } \\
\text { і вплив друзів }\end{array}$} \\
\hline & & так & ні & так & ні & так & ні & так & $\mathrm{Hi}$ & так & ні \\
\hline \multirow{2}{*}{$14-15$} & чоловіча & 2,0 & 5,0 & 4,5 & 2,5 & 4,5 & 2,5 & 4,0 & 3,0 & 5,0 & 1,0 \\
\hline & жіноча & 3,5 & 4,5 & 7,5 & 1,5 & 4,0 & 4,0 & 3,0 & 5,0 & 5,5 & 0,5 \\
\hline \multirow{2}{*}{$16-17$} & чоловіча & 4,0 & 6,0 & 8,0 & 2,0 & 8,0 & 2,0 & 5,0 & 5,0 & 9,5 & 0,5 \\
\hline & жіноча & 3,5 & 6,5 & 7,0 & 3,0 & 7,5 & 2,5 & 4,0 & 6,0 & 7,0 & 1,0 \\
\hline \multirow{2}{*}{$18-19$} & чоловіча & 2,5 & 3,5 & 4,0 & 2,0 & 4,0 & 2,0 & 3,0 & 3,0 & 5,5 & 0,5 \\
\hline & жіноча & 3,5 & 5,5 & 8,5 & 1,5 & 8,5 & 1,0 & 3,5 & 5,5 & 8,5 & 0,5 \\
\hline \multirow{2}{*}{ 20-21 } & чоловіча & 4,0 & 6,0 & 8,5 & 1,5 & 7,5 & 2,5 & 4,0 & 6,0 & 9,0 & 1,0 \\
\hline & жіноча & 4,5 & 5,5 & 9,0 & 1,0 & 8,5 & 1,5 & 4,5 & 5,5 & 8,5 & 1,5 \\
\hline \multirow{2}{*}{$22-23$} & чоловіча & 2,0 & 5,0 & 6,0 & 1,0 & 6,0 & 1,0 & 2,0 & 5,0 & 6,5 & 0,5 \\
\hline & жіноча & 2,0 & 6,0 & 7,5 & 1,5 & 6,5 & 1,5 & 2,0 & 6,0 & 7,0 & 1,0 \\
\hline \multirow{2}{*}{$24-25$} & чоловіча & 1,0 & 3,0 & 3,0 & 1,0 & 2,5 & 1,5 & 1,0 & 3,0 & 4,0 & 0,0 \\
\hline & жіноча & 1,0 & 5,0 & 4,5 & 1,5 & 4,5 & 1,5 & 1,0 & 5,0 & 5,5 & 0,5 \\
\hline \multirow{2}{*}{$>26$} & чоловіча & 0,5 & 1,5 & 1,0 & 1,0 & 1,0 & 1,0 & 0,5 & 1,5 & 2,0 & 0,0 \\
\hline & жіноча & 0,5 & 2,5 & 2,0 & 1,0 & 2,0 & 1,0 & 0,5 & 2,5 & 3,0 & 0,0 \\
\hline \multirow{2}{*}{ Разом } & чоловіча & 16,0 & 30,0 & 35,0 & 11,0 & 33,5 & 12,5 & 19,5 & 26,5 & 41,5 & 3,5 \\
\hline & жіноча & 18,5 & 35,5 & 43,0 & 11,0 & 41,0 & 13,0 & 18,5 & 35,5 & 50,0 & 5,0 \\
\hline
\end{tabular}

Із метою визначення характеристик факторного впливу на формування схильності до шкідливих звичок і майбутнього прийому токсичних речовин і наркотиків (табл. 4) поділили людей за віком на три групи: 14-17, 18-21 та понад 22 роки. Для розширення можливостей аналізу визначено середні статево-вікові величини та загальні середні факторні величини для кожного фактора. 
Вплив медико-біологічних факторів на схильності людини (\%)

\begin{tabular}{|c|c|c|c|c|c|c|c|c|c|c|c|c|c|}
\hline \multirow[t]{2}{*}{$\begin{array}{l}\text { Вік, } \\
\text { років }\end{array}$} & \multirow[t]{2}{*}{ Стать } & \multicolumn{2}{|c|}{$\begin{array}{c}\text { Народжен- } \\
\text { ня доно- } \\
\text { шеним }\end{array}$} & \multicolumn{2}{|c|}{$\begin{array}{c}\text { Раціональне } \\
\text { харчування }\end{array}$} & \multicolumn{2}{|c|}{$\begin{array}{c}\text { Фізичний } \\
\text { розвиток, стан } \\
\text { здоров’я - } \\
\text { самооцінка }\end{array}$} & \multicolumn{3}{|c|}{$\begin{array}{l}\text { Наслідки хвороб, } \\
\text { травм, отруєнь }\end{array}$} & \multicolumn{3}{|c|}{$\begin{array}{c}\text { Спадкова схильність } \\
\text { до шкідливих } \\
\text { звичок, наркоманії }\end{array}$} \\
\hline & & так & ні & так & ні & $\begin{array}{c}\text { задо- } \\
\text { вільно }\end{array}$ & $\begin{array}{l}\text { незадо- } \\
\text { вільно }\end{array}$ & $\begin{array}{l}\text { хво- } \\
\text { роби }\end{array}$ & травми & $\begin{array}{l}\text { отру- } \\
\text { єння }\end{array}$ & $\begin{array}{l}\text { алко- } \\
\text { голь }\end{array}$ & $\begin{array}{l}\text { стиму- } \\
\text { лятори }\end{array}$ & $\begin{array}{c}\text { нарко- } \\
\text { тики }\end{array}$ \\
\hline \multirow{2}{*}{$14-15$} & чоловіча & 6,0 & 1,0 & 3,0 & 4,0 & 4,5 & 2,5 & 2,5 & 1,5 & 1,0 & 2,5 & 4,5 & 0,0 \\
\hline & жіноча & 6,5 & 2,5 & 2,5 & 5,5 & 4,0 & 3,0 & 3,5 & 1,5 & 1,5 & 2,0 & 6,0 & 0,0 \\
\hline \multirow{2}{*}{$16-17$} & чоловіча & 8,5 & 2,5 & 3,5 & 6,5 & 4,5 & 5,5 & 4,0 & 1,0 & 0,5 & 3,0 & 7,5 & 0,5 \\
\hline & жіноча & 8,0 & 2,0 & 3,0 & 7,0 & 5,0 & 5,0 & 4,5 & 1,0 & 0,5 & 3,5 & 6,5 & 0,0 \\
\hline \multirow{2}{*}{ 18-19 } & чоловіча & 5,0 & 1,0 & 3,0 & 3,0 & 3,0 & 3,0 & 2,0 & 0,5 & 0,5 & 2,0 & 3,5 & 0,0 \\
\hline & жіноча & 7,5 & 1,5 & 4,0 & 5,0 & 3,5 & 5,5 & 1,5 & 0,5 & 0,5 & 0,5 & 5,0 & 0,0 \\
\hline \multirow{2}{*}{$20-21$} & чоловіча & 6,0 & 1,5 & 2,5 & 7,5 & 3,0 & 5,0 & 2,5 & 0,5 & 0,5 & 3,0 & 4,5 & 0,5 \\
\hline & жіноча & 7,5 & 1,0 & 4,0 & 5,0 & 4,5 & 5,5 & 4,0 & 1,0 & 0,5 & 1,5 & 4,0 & 0,0 \\
\hline \multirow{2}{*}{$22-23$} & чоловіча & 5,0 & 1,5 & 2,5 & 4,5 & 4,0 & 3,0 & 2,5 & 0,5 & 0,5 & 2,0 & 4,5 & 0,0 \\
\hline & жіноча & 6,0 & 1,5 & 3,0 & 5,0 & 3,0 & 3,5 & 3,0 & 1,0 & 1,0 & 0,5 & 3,5 & 0,0 \\
\hline \multirow{2}{*}{$24-25$} & чоловіча & 2,5 & 1,5 & 2,0 & 2,0 & 3,5 & 0,5 & 1,5 & 0,0 & 0,5 & 1,0 & 2,5 & 0,0 \\
\hline & жіноча & 4,5 & 1,5 & 2,0 & 4,0 & 4,0 & 1,5 & 1,0 & 0,5 & 0,5 & 1,5 & 3,5 & 0,0 \\
\hline \multirow{2}{*}{$>26$} & чоловіча & 2,0 & 1,0 & 1,0 & 2,0 & 4,0 & 1,0 & 1,0 & 0,0 & 0,0 & 1,0 & 1,0 & 0,0 \\
\hline & жіноча & 2,5 & 1,5 & 1,5 & 1,5 & 3,0 & 1,0 & 0,5 & 0,0 & 0,5 & 0,0 & 1,5 & 0,0 \\
\hline \multirow{2}{*}{ Разом } & чоловіча & 36,0 & 10,0 & 17,5 & 29,5 & 26,5 & 20,5 & 16,0 & 4,0 & 3,5 & 14,5 & 28,0 & 1,5 \\
\hline & жіноча & 42,5 & 11,5 & 20,0 & 33,0 & 27,0 & 26,0 & 18,0 & 5,5 & 5,0 & 9,5 & 30,0 & 0,0 \\
\hline
\end{tabular}

Табличя 4

Фактори впливу на формування схильності до шкідливих звичок і майбутнього прийому токсичних речовин і наркотиків (у частках від сукупності факторів)

\begin{tabular}{|c|c|c|c|c|c|c|c|c|}
\hline \multirow[b]{2}{*}{ Фактори впливу } & \multicolumn{2}{|c|}{ 14-17 років } & \multicolumn{2}{|c|}{ 18-21 рік } & \multicolumn{2}{|c|}{$>22$ роки } & \multicolumn{2}{|c|}{ Разом } \\
\hline & $\begin{array}{c}\text { чоловіча } \\
\text { стать }\end{array}$ & $\begin{array}{l}\text { жіноча } \\
\text { стать }\end{array}$ & $\begin{array}{c}\text { чоловіча } \\
\text { стать }\end{array}$ & $\begin{array}{l}\text { жіноча } \\
\text { стать }\end{array}$ & $\begin{array}{c}\text { чоловіча } \\
\text { стать }\end{array}$ & $\begin{array}{l}\text { жіноча } \\
\text { стать }\end{array}$ & $\begin{array}{c}\text { чоловіча } \\
\text { стать }\end{array}$ & $\begin{array}{c}\text { жіноча } \\
\text { стать }\end{array}$ \\
\hline Психологічні: & 0,3000 & 0,2425 & 0,2525 & 0,2600 & 0,2025 & 0,2125 & 0,7550 & 0,7150 \\
\hline -реакції протесту & 0,0375 & 0,0525 & 0,0325 & 0,0375 & 0,0025 & 0,0075 & 0,0725 & 0,0975 \\
\hline -реакції імітації & 0,1775 & 0,1000 & 0,1675 & 0,1375 & 0,1875 & 0,1300 & 0,4825 & 0,3675 \\
\hline - акцентуація характеру & 0,0850 & 0,0900 & 0,0675 & 0,0850 & 0,0625 & 0,0750 & 0,2150 & 0,2500 \\
\hline Соціальні: & 0,2875 & 0,3675 & 0,2550 & 0,2775 & 0,2550 & 0,2825 & 0,7975 & 0,9275 \\
\hline -заміжність & 0,0850 & 0,0900 & 0,0800 & 0,0950 & 0,0650 & 0,0850 & 0,2300 & 0,2700 \\
\hline - шлюб & 0,0225 & 0,0175 & 0,0175 & 0,0075 & 0,0150 & 0,0200 & 0,0550 & 0,0450 \\
\hline - сім'я & 0,0225 & 0,0325 & 0,0225 & 0,0125 & 0,0175 & 0,0200 & 0,0625 & 0,0650 \\
\hline - вік батьків & 0,0400 & 0,0900 & 0,0175 & 0,0215 & 0,0225 & 0,0125 & 0,0800 & 0,1250 \\
\hline - умови життя & 0,0400 & 0,0550 & 0,0450 & 0,0550 & 0,0525 & 0,0675 & 0,1375 & 0,1775 \\
\hline - вплив друзів & 0,0775 & 0,0825 & 0,0725 & 0,0850 & 0,0825 & 0,0775 & 0,2325 & 0,2450 \\
\hline Медико-біологічні: & 0,2275 & 0,2550 & 0,1900 & 0,2000 & 0,1550 & 0,1600 & 0,5750 & 0,6100 \\
\hline - доношеність & 0,0125 & 0,0175 & 0,0075 & 0,0125 & 0,0075 & 0,0075 & 0,0275 & 0,0375 \\
\hline - харчування & 0,0525 & 0,0625 & 0,0525 & 0,0500 & 0,0425 & 0,0525 & 0,1475 & 0,1650 \\
\hline - стан здоров'я & 0,0400 & 0,0450 & 0,0400 & 0,0550 & 0,0175 & 0,0250 & 0,0975 & 0,1200 \\
\hline - наслідки хвороб & 0,0325 & 0,0400 & 0,0225 & 0,0275 & 0,0250 & 0,0225 & 0,0800 & 0,0900 \\
\hline - спадкова схильність & 0,0900 & 0,0900 & 0,0675 & 0,0550 & 0,0625 & 0,0525 & 0,2200 & 0,1975 \\
\hline $\begin{array}{c}\text { Середнє значення для груп } \\
\text { психологічних, соціальних } \\
\text { і медико-біологічних } \\
\text { факторів }\end{array}$ & 0,2715 & 0,2550 & 0,2325 & 0,2455 & 0,2040 & 0,2180 & 0,7090 & 0,7505 \\
\hline
\end{tabular}

Перше рангове місце з багатофакторного впливу на формування схильності до шкідливих звичок і майбутнього прийому токсичних речовин і наркотиків у нашому 
дослідженні належить групі соціально-побутових факторів (загальний вплив - 0,79750,9275). Серед цих факторів найбільший - «вплив друзів» $(0,2325-0,2450)$. Імовірно, що чим більше друзів, тим більше варіантів до будь-якої схильності.

Друге рангове місце $(0,7150-0,7550)$ посідає група психологічних факторів (за даними сучасної медичної літератури, ця група посідає перше місце). Серед цієї групи найбільші значення факторного навантаження мають «реакції імітації» $(0,3675-0,4825)$. Імовірно, імітуючи «продвинуту» західну культуру та західний спосіб життя, респонденти робили спробу самоутвердження.

Третє рангове місце належить групі медико-біологічних факторів $(0,5750$ 0,6100). Найзначніший фактор цієї групи - спадкова схильність до можливого вживання психостимуляторів, токсичних речовин і наркотиків $(0,1975-0,2200)$.

Суспільство найчастіше не турбується про запобігання формуванню схильності до шкідливих звичок і майбутнього прийому токсичних речовин і наркотиків. Але ці схильності є лише невеликою частиною всього спектра залежностей, до якого належать зловживання алкоголем, залежність від медикаментів і куріння, а також токсичних речовин і наркотиків.

Спираючись на багатофакторний аналіз, виконали спробу пошуку раціональних шляхів первинної профілактики паління, вживання стимуляторів, алкоголю, токсичних речовин і наркотиків серед молоді. Основний напрям первинної профілактики - комплекс соціальних заходів із розробкою спеціальних профілактичних програм, що повинні відповідати культурі суспільства, особливостям регіону. Ці програми повинні враховувати всі особливості сучасної молоді. Другим напрямом профілактичних дій має бути індивідуальна та групова спеціальна психологічна робота. Треба зрозуміти, на якому логічному рівні перебувають свідомість, переконання підлітка із цього приводу. Ця робота повинна проходити у формі бесіди, під час якої виявляється сила значення для підлітка теми шкідливих речовин і наркотиків 3 адекватною соціальнопсихологічною корекцією. Третім напрямом профілактичних дій має бути відповідна медико-соціальна робота, яка б передбачала умови медичного забезпечення (європейський стандарт сімейної медицини) та людські умови життя. Всі три напрями мають бути об'єднані у вигляді програми дій із відповідним державним забезпеченням.

За допомогою нашої модифікації використання критерію відповіднисті $\chi^{2}$ визначено короткочасний прогноз можливої залежності людини від паління, уживання алкоголю, стимуляторів, токсичних і наркотичних речовин. За результатами короткочасного прогнозування, через 5 років передбачається зростання залежності серед підлітків і молоді від уживання алкоголю на 4,5 \%, стимуляторів - на 5,7 \%, токсичних, наркотичних речовин - на $0,25 \%$.

\section{Висновки}

Дослідження можливих схильностей до паління, вживання алкоголю, стимуляторів, токсичних, наркотичних речовин серед молоді показало, що перше рангове місце належить групі соціально-побутових факторів. Друге посідає група психологічних факторів, третє належить групі медико-біологічних факторів. Визначено можливі варіанти первинної профілактики цих схильностей:

1) створення комплексу соціальних заходів із розробкою спеціальних профілактичних програм, що повинні відповідати культурі суспільства та особливостям регіону;

2) індивідуальна та групова спеціальна психологічна робота, яка потребує 3'ясувати рівень міркувань на цю тему у підлітків та молоді; 
3) відповідна медико-соціальна робота, яка б передбачала людські умови медичного забезпечення (європейський стандарт сімейної медицини) та життя.

Виконано короткочасне прогнозування можливої залежності людини від паління, уживання алкоголю, стимуляторів, токсичних, наркотичних речовин.

\section{Бібліографічні посилання}

1. Березин С. В. Психологические особенности наркоманов периода взросления (опыт комплексного экспериментально-психологического исследования) / С. В. Березин, К. С. Лисецкий. - Самара : Самарский гос. ун-т, 1998. - 64 с.

2. Березин С. В. Психология наркотической зависимости и созависимости / С. В. Березин, К. С. Лисецкий, Е. А. Назаров. - Самара : Самарский гос. ун-т, 2001. - 164 с.

3. Гарифуллин Р. Р. Психокоррекция смысловых структур наркозависимой личности: Автореф. дисс. ... канд. психол. наук. - Казань, 2000. -20 с.

4. Гроф С. За проблемами мозга. - М. : Соцветие, 1992. - 336 с.

5. Клец Т. США против наркотиков. Эволюция психотерапии. - Т. 4. Иные голоса. - М. : Класс, 1998. $-144 \mathrm{c}$.

6. Наркоманія у підлітків / В. С. Битенский, Б. Г. Херсонський, С. В. Дворяк, В. А. Глушков. К. : Здоров'я, 1989. - $116 \mathrm{c.}$

7. Научно-методические основы первичной профилактики детской наркомании. - М. : Гос. НИИ семьи и воспитания, 2000. -96 с.

8. Россохин А. В. Проблема психотерапии наркомании // Проблемы интеграции академической и практической психологии. Тез. Междунар. конф. - Самара : Самарский гос. ун-т, 1999. C. $15-17$.

9. Саенко Ю. В. Специальная психология. - М. : Флинта, 2006. -224 с.

10. Юнак В. Ю. Наркоманія - шлях до безодні. - К. : Здоров'я, 2001. - 124 с.

11. Keating T. Divine Therapy and Addiction: Centering Prayer and the Twelve Steps. - Lantern Books, 2007. $-240 \mathrm{p}$.

Надійшла до редколегії 17.03.2012 